\title{
Optimasi Propilen Glikol dan Etanol sebagai Peningkat Penetrasi Ibuprofen dalam Sediaan Gel dengan Metode Simplex Lattice Design (Propylene Glycol and Ethanol Optimization as Ibuprofen Penetration Enhancer in Gel Dosage using Simplex Lattice Design Method)
}

\author{
Baiq Wahyudyati Karnia Qisti, Dwi Nurahmanto, Viddy Agustian Rosyidi \\ Fakultas Farmasi Universitas Jember \\ JIn. Kalimantan no. 37, Jember 68121 \\ e-mail korespondensi: dwinurahmanto.farmasi@unej.ac.id
}

\begin{abstract}
Ibuprofen is a non-steroid anti inflammatory drug (NSAID) used for rheumatoid arthritis treatment. In this study, formulation, evaluation, and optimization of ibuprofen gel formula were conducted in order to determine the best ibuprofen penetration rate through the rats skin using propylene glycol and ethanol as penetration enhancers and to find out the optimum formula to get the best penetration rate with simplex lattice design method. Evaluations included organoleptic, $\mathrm{pH}$, viscosity, gel dispersive, assay of gel formulations, and ibuprofen penetration rate assay. Penetration rate was determined by paddle type dissolution and the samples were analyzed by spectrophotometry UVVis. The results of ibuprofen penetration rate assay were analyzed and optimized using design expert trial version 10. The results of ibuprofen penetration rate were F1 $1.524 \pm$ $0.121 \mu \mathrm{g} / \mathrm{cm}^{2}$.minute; F2 $1.945 \pm 0.0104 \mu \mathrm{g} / \mathrm{cm}^{2}$.minute; and F3 $1.173 \pm 0.216$ $\mu \mathrm{g} / \mathrm{cm}^{2}$.minute. Penetration rate optimization resulted in one optimum solution formula which was $18.000 \%$ propylene glycol and $12.000 \%$ ethanol with a maximum flux of 1.957 $\mathrm{ug} / \mathrm{cm}^{2}$.minute and desirability 1 . It can be concluded that the best ibuprofen penetration rate was F2 with flux $1.945 \pm 0.0104 \mu \mathrm{g} / \mathrm{cm}^{2}$. minute with $15 \%$ propylene glycol and $15 \%$ ethanol.
\end{abstract}

Keywords: gel, ibuprofen, propylene glycol, ethanol, simplex lattice design

\begin{abstract}
Abstrak
Ibuprofen merupakan obat antiinflmasi non steroid (AINS) yang digunakan sebagai pengobatan rheumatoid arthritis. Pada penelitian ini dilakukan formulasi, evaluasi, dan optimasi formula gel ibuprofen dengan tujuan untuk mengetahui penetrasi ibuprofen yang paling baik melalui kulit tikus menggunakan propilen glikol dan etanol sebagai peningkat penetrasi serta mengetahui formula optimum untuk mendapatkan laju penetrasi terbaik dengan metode simplex lattice design. Evaluasi yang dilakukan meliputi uji organoleptis, $\mathrm{pH}$, viskositas, daya sebar, kadar gel, dan laju penetrasi ibuprofen dalam gel. Laju penetrasi ditentukan menggunakan disolusi tipe dayung dan sampel dianalisis dengan spektrofotometri UV-Vis. Hasil laju penetrasi dianalisis dan dioptimasi menggunakan design expert trial versi 10. Hasil fluks penetrasi F1 1,524 $\pm 0,121 \mu \mathrm{g} / \mathrm{cm}^{2}$.menit; F2 1,945 $\pm 0,0104 \mu \mathrm{g} / \mathrm{cm}^{2}$.menit; dan F3 1,173 $\pm 0,216 \mu \mathrm{g} / \mathrm{cm} 2$.menit. Hasil optimasi laju penetrasi menghasilkan satu solusi formula optimum yaitu 18,000\% propilen glikol dan $12,000 \%$ etanol dengan fluks maksimal $1,957 \mu \mathrm{g} / \mathrm{cm}^{2}$.menit dan desirability 1 . Berdasarkan penelitian, formula 2 (F2) memiliki laju penetrasi yang paling baik yaitu $1,945 \pm 0,0104$ $\mu \mathrm{g} / \mathrm{cm}^{2}$.menit dengan komposisi $15 \%$ propilen glikol dan $15 \%$ etanol.
\end{abstract}

Kata kunci: gel, ibuprofen, propilen glikol, etanol, simplex lattice design 


\section{Pendahuluan}

Ibuprofen merupakan obat antiinflamasi non steroid (AINS) yang biasa digunakan untuk terapi rheumatoid arthritis akut dan kronis [1]. Ibuprofen adalah obat turunan asam propionat dengan aktivitas antiinflamasi, analgesik, dan antipiretik. Secara umum AINS memiliki mekanisme aksi dengan menghambat sintesis asam arakidonat menjadi prostaglandin melalui enzim siklooksigenase (COX). AINS memiliki beberapa efek samping yaitu gangguan saluran gastrointestinal diantaranya ulserasi dan hemoragi, toksisitas renal, inhibisi pembentukan platelet sehingga dapat menimbulkan kelainan koagulasi apabila diminum secara oral [2], tetapi ibuprofen memiliki efek samping lebih kecil dibandingkan dengan obat antiinflamasi non steroid lainnya [1].

Kulit manusia terdiri dari beberapa lapisan yaitu epidermis, dermis, dan hipodermis. Stratum korneum merupakan lapisan pada epidermis yang paling atas yang bertugas sebagai barrier hilangnya air dalam tubuh dan penetrasi bahan-bahan asing serta memberikan proteksi mekanis [3].

Obat berdifusi ke dalam kulit melalui kontak langsung dengan kulit menuju ke dalam epidermis maupun dermis sebagai situs target obat [4]. Rute penetrasi terbagi atas dua yaitu rute penetrasi secara transepidermal dan transapendageal. Rute penetrasi kulit secara transepidermal terbagi lagi menjadi dua yaitu interselular dan transelular. Rute transelular merupakan rute langsung dimana obat akan menembus ke dalam kulit dengan melewati lapisan lemak di stratum korneum. Rute transapendageal mentranspor obat melalui kelenjar keringat dan rambut-rambut pada kulit [5].

Salah satu sediaan transdermal yang paling banyak digunakan adalah gel. Gel merupakan sistem semi padat dimana fase cairnya terikat didalam matriks polimer sintetis maupun bahan alam yang memiliki struktur kompleks ikatan silang [6]. Sistem penghantaran obat secara transdermal memiliki keuntungan yaitu first-pass metabolism dapat dihindari dan dosis pemberiannya tidak terlalu sering [7].

Ibuprofen merupakan obat yang tergolong dalam Biopharmaceutics Classification System II (BCS II) dimana obat tersebut kelarutannya rendah tetapi memiliki permeabilitas membran yang baik [8]. Agar dapat berpenetrasi dengan baik ke dalam kulit, perlu dilakukan sebuah metode untuk meningkatkan kelarutan ibuprofen dalam pelarutnya. Metode yang dapat dilakukan untuk meningkatkan kelarutan obat dengan kelarutan rendah adalah pembuatan dispersi padat [9]. Perbandingan ibuprofen : PEG 6000 yang menunjukkan hasil karakter fisika kimia dan kelarutan terbaik adalah 1:1,5 [10].

Selain faktor kelarutan yang mempengaruhi laju penetrasi sebuah obat, kemampuan obat untuk menembus kulit (stratum korneum) juga sangat mempengaruhi. Propilen glikol dan etanol tergolong dalam alkohol yang dapat berfungsi sebagai pembawa, pelarut, dan bahkan peningkat penetrasi bahan obat ke dalam kulit (stratum korneum) pada sistem penghantaran transdermal. Propilen glikol dan etanol dapat meningkatkan permeasi ke dalam kulit dengan mekanisme ekstraksi lemak dan protein, swelling pada stratum korneum atau meningkatkan koefisien partisi dan kelarutan obat dalam formulasi [11].

Penelitian ini dilakukan untuk mengetahui pengaruh kombinasi propilen glikol dan etanol terhadap laju penetrasi ibuprofen dalam sediaan gel dispersi padat ibuprofen : PEG 6000 1:1,5 dengan menggunakan kulit tikus sebagai media penetrasi. Penelitian ini juga dilakukan untuk menentukan formula optimum menggunakan metode simplex lattice design dengan software design expert trial versi 10.

\section{Metode Penelitian}

Penelitian ini dilakukan secara eksperimental laboratorik. Tahapan yang dilakukan pada penelitian ini adalah pembuatan dispersi padat, pembuatan gel, pengujian sifat fisika kimia meliputi pengujian $\mathrm{pH}$, pengujian daya sebar, pengujian viskositas, pengujian kadar gel, pengujian laju penetrasi ibuprofen, dan optimasi formula gel.

Alat yang digunakan dalam penelitian ini adalah spektrofotometer UV-Vis (Genesys 10S Uv-Vis), alat uji disolusi tipe dayung (Logan), viskotester (Viscometer Rion VT-04), pH meter (Elmetron), alat uji daya sebar, waterbath (Memmert), neraca analitik (Centarus Scale), desikator (Normax), oven (Memmert), ultrasonik (Elmasonic $\mathrm{E} \mathrm{30H).}$

Bahan yang digunakan dalam penelitian ini adalah ibuprofen (didapat dari PT. Indofarma), propilen glikol (PT. Bratachem), etanol 96\% (PT. Bratachem), trietanolamin (PT. Tristarchem), karbopol 940 (PT. Tristarchem), natrium hidroksida ( $\mathrm{NaOH})$ (PT. Bratachem), natrium fosfat dibasik $\left(\mathrm{Na}_{2} \mathrm{HPO}_{4}\right)$ (PT. Bratachem), kalium fosfat dibasik $\left(\mathrm{K}_{2} \mathrm{HPO}_{4}\right)$ (PT. 
Bratachem), natrium klorida ( $\mathrm{NaCl})$ (PT. Bratachem), kalium klorida (KCl) (PT. Bratachem), asam klorida ( $\mathrm{HCl}) \quad$ (PT. Bratachem), dan akuadestilata.

Dispersi padat dibuat dengan cara meleburkan ibuprofen dan PEG 6000 1:1,5 pada suhu $80^{\circ} \mathrm{C}$ di atas waterbath kemudian segera didinginkan di icebath dan disimpan dalam desikator selama 24 jam. Selanjutnya diuji kadar ibuprofen dalam dispersi padat. Gel ibuprofen dibuat dengan cara melarutkan dispersi padat ibuprofen dalam etanol dan propilen glikol sesuai formula kemudian dituangkan sedikit demi sedikit dalam basis gel yaitu carbopol yang sebelumnya sudah didispersikan dalam akuades bebas dan ditambah TEA. Campuran kemudian diaduk sampai terbentuk massa gel. Susunan formula gel dapat dilihat pada Tabel 1.

Tabel 1. Susunan formula gel Ibuprofen

\begin{tabular}{|c|c|c|c|}
\hline Bahan & $\mathrm{F} 1(\%)$ & $\mathrm{F} 2(\%)$ & $\mathrm{F} 3(\%)$ \\
\hline $\begin{array}{l}\text { Dispersi padat ibuprofen : } \\
\text { PEG } 6000\end{array}$ & 2.77 & 2.77 & 2.77 \\
\hline Karbopol 940 & 1 & 1 & 1 \\
\hline Propilen glikol & 30 & 15 & 0 \\
\hline Etanol & 0 & 15 & 30 \\
\hline Trietanolamin (TEA) & 2 & 2 & 2 \\
\hline Akuades bebas $\mathrm{CO}_{2}$ & $\begin{array}{c}\text { hingga } \\
100\end{array}$ & $\begin{array}{c}\text { hingga } \\
100\end{array}$ & $\begin{array}{l}\text { hingga } \\
100\end{array}$ \\
\hline Berat total & 100 & 100 & 100 \\
\hline
\end{tabular}

Pengujian yang dilakukan meliputi:

a. Organoleptis

Uji organoleptis berupa pengamatan terhadap warna, bau, bentuk, dan kejernihan gel. Sediaan gel yang baik memiliki kriteria fisik warna bening, tidak berbau atau bau lemah, dan bentuk berupa gel.

b. $\mathrm{pH}$

Pengujian $\mathrm{pH}$ dilakukan dengan cara menimbang gel sebanyak 1 gram kemudian dilarutkan dalam akuades. Nilai $\mathrm{pH}$ diukur dengan $\mathrm{pH}$ meter. Syarat $\mathrm{pH}$ yang aman dan tidak mengiritasi kulit adalah 6-7,5 [12].

c. Viskositas

Gel ditimbang sebanyak 50 gram di dalam gelas beker kemudian ditentukan viskositasnya dengan alat visko meter. Viskosotas sediaan gel yang baik adalah di bawah $150 \mathrm{dPa}$.s [13].

d. Daya sebar

Gel sebanyak 1 ditimbang kemudian diletakkan di antara 2 plat kaca yang memiliki skala dan diberi beban di atas plat. Waktu pemberian beban adalah 1 menit. Sebaran gel yang baik pada kulit adalah 5-7 cm [14].

e. Kadar gel

Gel ditimbang sejumlah tertentu hingga mengandung konsentrasi ibuprofen sebesar $15 \mathrm{ppm}$. Kemudian gel dilarutkan dalam larutan dapar fosfat salin $\mathrm{pH} 7,4$ dan diamati serapannya dengan spektrofotometer pada panjang gelombang maksimalnya.

h. Laju penetrasi in vitro

Gel dimasukkan pada bagian tengah cakram, sedangkan kulit dipasang antara kompartemen sel difusi dengan epidermis menghadap kompartemen donor kemudian ditempatkan ke dalam alat uji disolusi. Pengujian ini dilakukan dengan medium disolusi $500 \mathrm{~mL}$ dapar fosfat salin $\mathrm{pH} 7,4 \pm$ 0,05 dengan kecepatan putar $50 \mathrm{rpm}$ dilakukan selama 8 jam. Sampel diambil dari kompartemen reseptor sebanyak $5 \mathrm{~mL}$ kemudian dianalisis dengan menggunakan spektofotometer UV-Vis pada panjang gelombang maksimum.

\section{Hasil Penelitian}

Dispersi padat yang dihasilkan berupa serbuk halus berwarna putih. $\mathrm{Hal}$ ini menunjukkan bahwa ibuprofen telah terdispersi secara homogen karena ibuprofen murni berwarna putih. Persen recovery kadar ibuprofen adalah 90,167\%. Hal ini disebabkan ada massa yang hilang dalam proses pembuatan.

Gel ibuprofen yang dihasilkan memiliki bentuk gel, tidak berwarna, tidak berbau pada formula 1 sedangkan pada formula 2 dan formula 3 terdapat bau lemah etanol. Hasil organoleptis gel ibuprofen dapat dilihat pada Gambar 1.

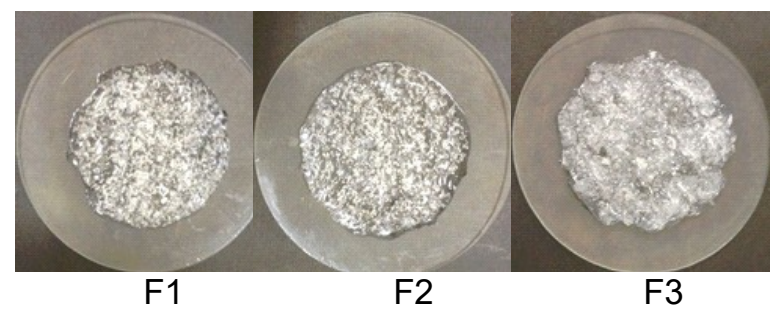

Gambar 1. Gel ibuprofen yang dihasilkan memiliki bentuk gel, tidak berwarna, tidak berbau pada formula 1 sedangkan pada formula 2 dan formula 3 terdapat bau lemah etanol. 
Hasil pengujian $\mathrm{pH}$ menunjukkan bahwa $\mathrm{pH}$ sediaan yang dihasilkan dari keempat formula telah memenuhi kriteria rentang $\mathrm{pH}$ yang tidak mengiritasi kulit yaitu 6-7,5. Sediaan gel yang baik adalah gel yang memiliki viskositas dibawah 150 dPa.s, hasil semua formula gel menunjukkan bahwa viskositas memenuhi kriteria yang diinginkan. Hasil daya sebar gel menunjukkan hasil yang memenuhi kriteria yaitu diameter sebar gel berada pada rentang 5-7 cm kecuali pada formula 3 yang diameter sebarnya tidak sampai $5 \mathrm{~cm}$. Hasil evaluasi gel dapat dilihat pada Tabel 2 .

Hasil uji kadar gel menunjukkan kriteria yang sesuai yaitu kadar analit $1 \%$ tidak kurang dari $97 \%$ dan tidak lebih dari $103 \%$ dengan CV $<2,7 \%$. Berdasarkan data fluks yang didapatkan, F3 memiliki nilai yang paling kecil diantara formula lainnya dengan etanol sebagai peningkat penetrasi. F2 memiliki nilai fluks yang paling tinggi dibandingkan F1 dan F3 karena adanya campuran propilen glikol dan etanol sebagai peningkat penetrasi. Hasil pengujian kadar dan fluks dapat dilihat pada Tabel 3. Hasil pentrasi gel ibuprofen ditunjukkan oleh gambar 2.

Tabel 2. Hasil evaluasi gel

\begin{tabular}{cccc}
\hline & $\mathrm{pH}$ & $\begin{array}{c}\text { Viskositas } \\
(\mathrm{dPa} . \mathrm{s})\end{array}$ & $\begin{array}{c}\text { Daya sebar } \\
(\mathrm{cm})\end{array}$ \\
\hline $\mathrm{F} 1$ & $6,54 \pm 0,0473$ & $106,67 \pm 2,887$ & $4,93 \pm 0,15$ \\
F2 & $6,87 \pm 0,0322$ & $100,00 \pm 0,000$ & $5,27 \pm 0,06$ \\
F3 & $6,65 \pm 0,0200$ & $100,00 \pm 0,000$ & $5,00 \pm 0,01$
\end{tabular}

Keterangan: $\mathrm{F} 1=30 \%$ propilen glikol dan $0 \%$ etanol, $\mathrm{F} 2=15 \%$ propilen glikol dan $15 \%$ etanol, $\mathrm{F} 3=0 \%$ propilen glikol dan $30 \%$ etanol. Data disajikan dalam rerata $\pm S D(n=3)$.

Tabel 3. Hasil uji kadar dan fluks gel ibuprofen

\begin{tabular}{ccc}
\hline & Kadar ibuprofen $(\%)$ & Fluks $\left(\mu \mathrm{g} / \mathrm{cm}^{2}\right.$.menit $)$ \\
\hline F1 & $98,848 \% \pm 1,133$ & $1,524 \pm 0,121$ \\
F2 & $97,940 \% \pm 1,050$ & $1,945 \pm 0,0104$ \\
F3 & $98,505 \% \pm 1,679$ & $1,173 \pm 0,216$ \\
\hline
\end{tabular}

Keterangan: $\mathrm{F} 1=30 \%$ propilen glikol dan $0 \%$ etanol, $\mathrm{F} 2=15 \%$ propilen glikol dan $15 \%$ etanol, $\mathrm{F} 3=0 \%$ propilen glikol dan $30 \%$ etanol. Data disajikan dalam rerata $\pm S D(n=3)$.

Hasil optimasi respon fluks dengan software design expert trial versi 10 menggunakan metoe simplex lattice. Hasil yang didapatkan berupa solution, grafik two component mix, grafik prediksi, dan grafik desirability ditunjukkan oleh Tabel 4, Gambar 3, Gambar 4, Gambar 5, Persamaan 1, dan Persamaan 2.

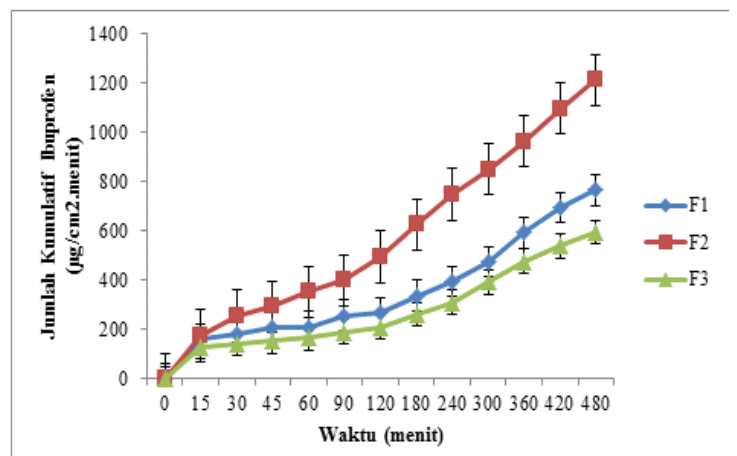

Gambar 2. Grafik penetrasi gel ibuprofen

Tabel 4. Hasil optimasi respon flluks

\begin{tabular}{ccccc}
\hline Number & $\begin{array}{c}\text { Propilen } \\
\text { glikol }\end{array}$ & Etanol & Fluks & Desirability \\
\hline 1 & $18.00 \%$ & $12.00 \%$ & 1.96 & 1 \\
\hline
\end{tabular}

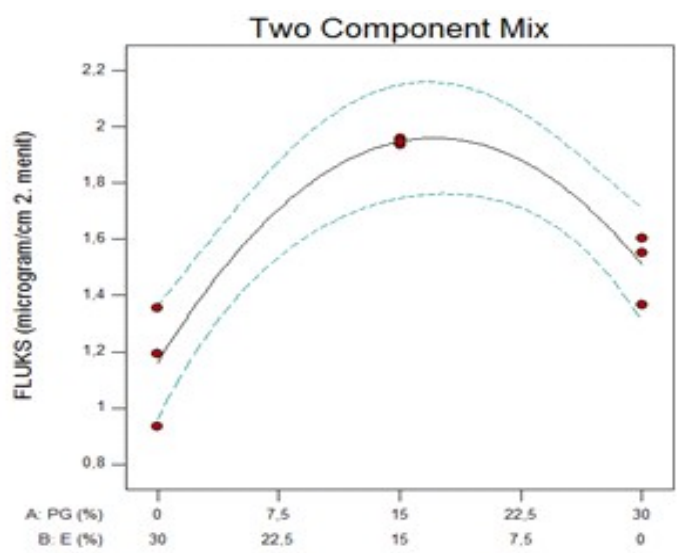

Gambar 3. Grafik two component mix

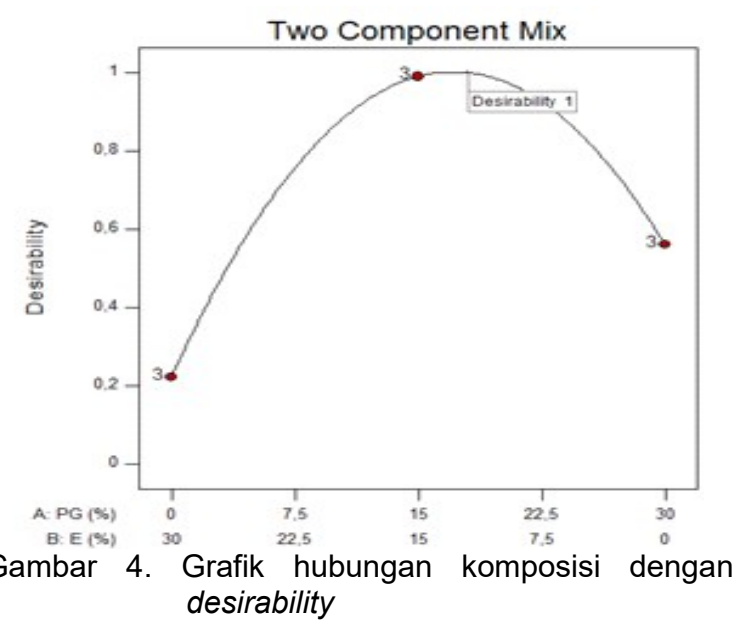




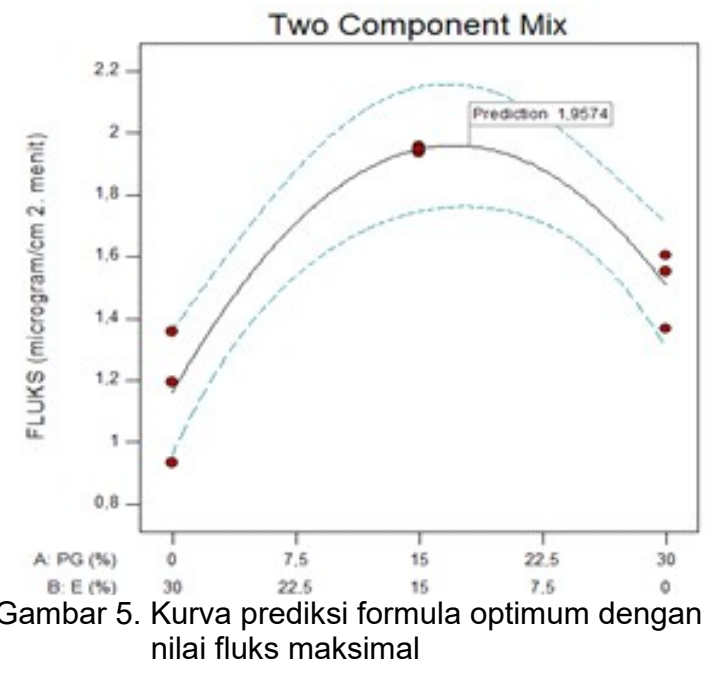

Persamaan 1. Final equation in terms of real components

$Y=+1,50767$ propilen glikol $+1,16200$ etanol $+2,45000$ propilen glikol etanol. Persamaan 2. Final equation in terms of actual
components

$\mathrm{Y}=+0,050256$ propilen glikol $+0,038733$ etanol $+0,00272222$ propilen glikol etanol.

\section{Pembahasan}

Dispersi padat ibuprofen : PEG 6000 perbandingan 1:1,5 dibuat dengan metode peleburan. Pembuatan dispersi padat dilakukan dengan tujuan untuk mempercepat kelarutan ibuprofen. PEG 6000 dipilih karena kelazimannya sebagai pembawa dan dari hasil FTIR menunjukkan bahwa ibuprofen dan PEG 6000 tidak memiliki ikatan atau interaksi kimia karena pita absorpsi yang utama pada ibuprofen dan PEG 6000 tetap muncul pada bilangan gelombang yang sama. Ibuprofen dalam dispersi padat akan dikelilingi oleh pembawa yaitu PEG sehingga kelarutan ibuprofen akan meningkat [15].

Data hasil pengujian $\mathrm{pH}$ menunjukkan bahwa $\mathrm{pH}$ dari masing-masing formula memenuhi kriteria $\mathrm{pH}$ sediaan yang dapat ditoleransi dan tidak mengiritasi kulit. Hasil menunjukkan bahwa $\mathrm{pH}$ masing-masing formula adalah berbeda. Nilai pH F2 menunujukkan campuran propilen glikol dan etanol memberikan $\mathrm{pH}$ paling tinggi dibandingkan penggunaan propilen glikol dan etanol.

Hasil dari ketiga formula menunjukkan bahwa sediaan gel telah memenuhi kriteria viskositas yang baik berdasarkan literatur [13].
Viskositas terbesar terdapat pada F1 karena adanya propilen glikol dalam jumlah yang banyak yaitu $30 \mathrm{ml}$ sehingga meningkatkan viskositas sediaan, sedangkan pada F2 dan F3 memiliki viskositas yang sama. Perbedaan nilai viskositas ketiga formula tersebut dapat juga disebabkan oleh viskositas masing-masing bahan yaitu propilen glikol dan etanol. Viskositas etanol adalah 1,22 mPa.s dan viskositas propilen glikol adalah 58,1 mPa.s [16].

Berdasarkan hasil pengujian daya sebar, F1 memiliki daya sebar paling kecil dibandingkan F2 dan F3 dan tidak memenuhi persyaratan literatur [14]. Hal ini disebabkan oleh viskositas $\mathrm{F} 1$ yang lebih tinggi dibanding F2 dan F3 sehingga juga mempengaruhi kemampuan penyebaran gel. Semakin meningkatnya viskositas sediaan topikal akan meningkatkan waktu kontaknya dengan kulit tetapi pada saat yang sama juga akan menurunkan kemampuan daya sebar sediaan [14].

Pengujian laju penetrasi ibuprofen memiliki tujuan untuk mengetahui jumlah ibuprofen yang tertranspor ke dalam kulit tikus per satuan luas tiap waktu. Ibuprofen yang dapat terlepas dari basis akan tertranspor ke dalam medium disolusi melalui membran yaitu kulit tikus. . Nilai fluks merupakan slope dari hasil regresi antara kadar kumulatif ibuprofen terhadap waktu pada steady state. Kondisi steady state ditunjukkan dengan gambaran kurva yang linier. Kurva linier memiliki nilai koefisien korelasi ( $r$ ) sama dengan atau mendekati 1. Berdasarkan hasil, setelah dilakukan uji penetrasi selama 8 jam maka terlihat bahwa kadar ibuprofen semakin meningkat seiring dengan bertambahnya waktu penetrasi. Formula 2 (F2) dengan agen peningkat penetrasi campuran etanol dan propilen glikol memiliki nilai fluks tertinggi yaitu $1,945 \mu \mathrm{g} / \mathrm{cm}^{2}$.menit kemudian $\mathrm{F} 1$ dengan nilai fluks $1,524 \mu \mathrm{g} / \mathrm{cm}^{2}$. menit, dan terakhir adalah F3 dengan nilai fluks $1,173 \mu \mathrm{g} / \mathrm{cm}^{2}$.menit. Hal ini dapat dipengaruhi oleh sinergisme propilen glikol dan etanol dalam meningkatkan laju penetrasi sebuah bahan aktif obat [17]. Secara individu etanol dan propilen glikol memiliki mekanisme yang mirip untuk meningkatkan laju penetrasi bahan obat diantaranya sebagai kosolven untuk meningkatkan kelarutan obat, mengganggu susunan lemak pada stratum korneum, dan dapat mengubah aktivitas termodinamika pada stratum korneum sehingga kedua bahan tersebut dapat memfasilitasi obat 
untuk menembus kulit dan meningkatkan jumlah obat yang terpenetrasi ke dalam kulit [18].

Selanjutnya data fluks dianalisa menggunakan software design expert trial versi 10. Hasil diuji dengan One Way ANOVA yang terdapat pada design expert. Berdasarkan hasil analisa, ketiga formula memiliki perbedaan yang signifikan karena nilai $p=0,0012$. Sebuah data dikatakan signifikan apabila memiliki nilai $p$ $<0,05$. Analisa fluks dengan design expert juga akan menghasilkan persamaan yang memberikan prediksi faktor mana yang memberikan pengaruh lebih signifikan pada hasil fluks. Persamaan hasil respon fluks adalah persamaan 1 dan persamaan 2 .

Berdasarkan persamaan Terms of real components di atas, masing-masing komponen memiliki nilai positif yang berarti masing-masing faktor yaitu propilen glikol dan etanol memiliki pengaruh terhadap hasil fluks yakni dapat meningkatkan fluks ibuprofen, sedangkan gabungan keduanya memiliki nilai positif yang paling tinggi. Hal tersebut menandakan bahwa penggunaan agen peningkat penetrasi ganda dapat meningkatkan fluks ibuprofen lebih baik daripada penggunaan tunggal. Terms of actual components menjelaskan hasil asli dari fluks penetrasi yang telah dilakukan apabila jumlah dari masing-masing faktor dikalikan dengan persamaan tersebut.

Penentuan formula optimum dilakukan dengan mengolah data respon fluks yang memenuhi kriteria dengan software design expert trial versi 10. Pada penelitian ini nilai fluks yang diinginkan adalah nilai fluks maksimal. Hasil optimasi yang dihasilkan dari software design expert adalah berupa tabel solution, grafik two component mix, grafik prediksi, dan grafik desirability. Grafik two component mix, grafik prediksi, dan grafik desirability berturutturut ditunjukkan oleh gambar 3 , gambar 4 , dan gambar 5 .

Pada grafik two component mix garis paling atas menunjukkan fluks penetrasi ibuprofen yang paling baik dari masing-masing replikasi pada tiap formula, sedangkan garis paling bawah adalah fluks yang paling rendah dari masing-masing replikasi pada tiap formula. Desirability menjelaskan seberapa dekat komposisi formula optimum yang diprediksi oleh design expert dengan fluks maksimal. Desirability ditunjukkan oleh angka mulai 0 hingga 1 , semakin mendekati angka 1 maka formula semakin dekat dengan fluks maksimal yang diinginkan.

\section{Simpulan dan Saran}

Penambahan agen peningkat penetrasi campuran yaitu propilen glikol dan etanol dapat meningkatkan laju penetrasi ibuprofen lebih baik dibanding penggunaan agen peningkat penetrasi tunggal. Urutan formula dengan laju penetrasi tertinggi adalah $\mathrm{F} 2>\mathrm{F} 1>\mathrm{F} 3$ dengan nilai fluks masing masing $1,945 \mu \mathrm{g} / \mathrm{cm}^{2}$. menit; $1,524 \mu \mathrm{g} / \mathrm{cm}^{2}$. menit; dan $1,205 \mu \mathrm{g} / \mathrm{cm}^{2}$. menit. Komposisi optimum campuran propilen glikol dan etanol yang dapat meningkatkan laju penetrasi ibuprofen paling baik menurut metode simplex lattice design dari software design expert trial versi 10 adalah $18,000 \%$ propilen glikol dan $12,000 \%$ etanol dengan fluks 1,957 $\mathrm{\mu g} / \mathrm{cm}^{2}$. menit dan desirability 1,000 .

Perlu dilakukan uji stabilitas untuk mengetahui pengaruh lama penyimpanan dan suhu terhadap stabilitas fisik dan kimia dispersi padat dan sediaan gel ibuprofen : PEG 6000. Perlu dilakukan penelitian mengenai uji iritasi sediaan gel dispersi padat ibuprofen : PEG 6000 karena sediaan mengandung etanol dalam jumlah yang cukup banyak.

\section{Daftar Pustaka}

[1] Sweetman SC, editor. Martindale the complete drug reference. $36^{\text {th }}$ ed. London and Chicago: Pharmaceutical Press. 2009.

[2] Bushra R, Aslam N. An overview of clinical pharmacology of ibuprofen. Oman Med J. 2010; 25(3): 155-161

[3] Freinkel RK, Woodley DT. The biology of the skin. US: The Parthenon Publishing Group Inc. 2000.

[4] Moser K, Kriwet K, Naik A, Kalia YN, Guy $\mathrm{RH}$. Passive skin penetration enhancement and its quantification in vitro. Eur $\mathrm{J}$ Pharm Biopharm. 2001; 52: 103-112.

[5] Trommer H, Neubert RHH. Overcoming the stratum corneum: the modulation of skin penetration. Skin Pharmacol Physiol. 2006; 19: 106-121.

[6] Bharadwaj S, Gupta GD, Sharma VK. Topical gel: a novel approach for drug delivery. J Chem Bio Physic Sci. 2012; 2(2): 856-867.

[7] Hamman JH, Fox LT, Gerber M, Du Plessis J. Transdermal drug delivery enhancement by compounds of natural origin. Molecules. 2011; 16: 10507-10540

[8] Alvarez C, Nunez I, Torrado JJ, Gordon J, Potthast H, Garcia-Arieta A. Investigation on the possibility of biowaivers for ibuprofen. $\mathrm{J}$ 
Pharm Sci. 2011; 100(6): 2343-2349.

[9] Bajaj H, Bisht S, Yadav M, Singh V. Bioavailability enhancement: a review. Int $\mathrm{J}$ Pharm Bio Sci. 2011; 2(2): 202-216.

[10]]Dabbagh MA, Taghipour B. Investigation of solid dispersion technique in improvement of physicochemical characteristics of ibuprofen powder. Iranian J Pharm Sci. 2007; 3(2): 6976.

[11]Karande P, Mitragotri S. Enhancement of transdermal drug delivery via sinergistic action of chemicals. Biochim Biophys Acta. 2009; 1788: 2362-2373.

[12] Najmuddin N, Mohsin AA, Khan T, Patel V, Shelar S. Formulation and evaluation of solid dispersion incorporated gel of ketoconazole. Res J Pharm Bio Chem Sci. 2010; 1(2): 406-412.

[13] United State. US Patents. Topical low- viscosity gel composition. United State. Dow GJ, Lathrop RW, Dow AD. 2002.

[14]Garg A, Aggarwal D, Garg S, Singla AK. Spreading of semisolid formulations: an update. Pharm Tech. 2002.

[15]Chiou WL, Reigelman S. Pharmaceutical applications of solid dispersion systems. J. Pharm Sci. 1971; 60(9): 1281-1302.

[16]Rowe RC, Paul JS, Marian EQ. Handbook of pharmaceutcal excipients. $6^{\text {th }}$ ed. United State: Pharmaceutical Press and American Pharmacists Association. 2009.

[17]Lane ME. Skin Penetration enhancer. Int J Pharm. 2013; 447: 12-21.

[18]Williams AC, Barry BW. Penetration enhancer advance drug delivery review. 2012; 64: 128-137. 